\title{
SMOKING, CANING, AND DELINQUENCY IN A SECONDARY MODERN SCHOOL
}

\author{
BY \\ J. W. PALMER \\ Medical Research Council Epidemiological Research Unit (South Wales), Cardiff
}

This study was designed in 1962 to investigate the reformative effect of a particular punishment (caning) for a particular offence (smoking by schoolboys). In 1964 , in the course of a larger study of juvenile offences, delinquency records were obtained from the police, and the relationship between smoking and delinquency is also discussed in this paper.

\section{METHODS}

The study was carried out in a secondary modern co-educational school in a South Wales mining valley. The Headmaster said that he always caned boys for smoking, and in view of this fact an attempt was made to see whether this punishment had a reformative effect.

Since the Headmaster kept a record of boys caned, he was able to provide a list of all boys caned for smoking during the preceding academic year (September, 1961, to July, 1962). There were 23 boys on the list, all from the 2nd, 3rd, and 4th forms (the three senior years). It was accordingly decided to interview all boys in these forms about their present and past smoking habits. There were 147 of these boys, their mean age in November, 1962, being 13 years 10 months (range 12 years 1 month to 15 years 7 months).

The boys were interviewed singly in private by the writer. It was explained to each one that the information he gave would be kept secret. 126 boys were interviewed in school on a single day (November 22, 1962) and another twelve 6 days later; the remaining nine were contacted at home (or, in one case, in hospital).

It was thought that the validity of the responses might be reduced if the boys knew that the survey had anything to do with punishment, so this fact was concealed, and each boy was asked the following questions:

(1) "How much do you smoke now?"

(2) "How much used you to smoke about September last year?"

The replies were recorded on a 5-point scale of cigarettes per week: none; $<5 ; 5-14 ; 15-24 ;>24$.

The second stage of information gathering took place in May, 1964, when, in the course of a larget study of juvenile offences, police records were? examined to see whether any of the boys had been found guilty of, or officially cautioned for, any offence. ("Cautioning", in this context, means not a simple admonition by a constable but the formal procedure by which a juvenile who admits the offence is warned by a police officer of at least Inspector's rank, in the presence of his parents, as an alternative to prosecution. It is used only with the approval of the Chief Constable, usually for first offences.) One boy was found to have left the district, so that if he had a record of delinquency it was not available; he has therefore been omitted from the analysis, reducing the total number to 146 .

\section{Prevalence of Delinquency}

In May, 1964, the mean age of the 146 boys was 15 years 4 months* (range 13 years 7 months to 17 years 1 month), and 38 (26.0 per cent.) had delinquent records. Subtraction of those who were cautioned only, and had never been found guilty in court, left 31 offenders $(21 \cdot 2$ per cent.). Table I (opposite) shows the numbers of boys who had committed offences of particular kinds. 33 boys ( 22.6 per cent. of the 146$)$

* Exclusion of the boy who left the area altered the mean age by 18
* Exclusion of the
less than one month. 
TABLE I

OFFENCES COMMITTED IN ORDER OF FREQUENCY

\begin{tabular}{|c|c|c|c|c|}
\hline Offence & & & $\begin{array}{l}\text { No. } \\
\text { of Boys }\end{array}$ & $\begin{array}{l}\text { Per cent. of } \\
\text { Total } 146\end{array}$ \\
\hline $\begin{array}{l}\text { Larceny } \\
\text { Trespass on the Railway } \\
\text { Breaking and Entering } \\
\text { Malicious Damage } \\
\begin{array}{l}\text { Receiving } \\
\text { Firearm Offences }\end{array} \text {. } \\
\text { Indecent Assault } \\
\begin{array}{l}\text { Driving under Age } \\
\text { Keeping Dangerous Dog }\end{array}\end{array}$ & $\begin{array}{l}\cdots \\
\cdots \\
\cdots \\
\cdots \\
\cdots \\
\cdots \\
\cdots\end{array}$ & $\begin{array}{l}\ldots \\
\cdots \\
\cdots \\
\cdots \\
\cdots \\
\cdots \\
\cdots\end{array}$ & $\begin{array}{r}27 \\
9 \\
8 \\
8 \\
3 \\
2 \\
1 \\
1 \\
1\end{array}$ & $\begin{array}{r}18 \cdot 5 \\
6 \cdot 2 \\
5 \cdot 5 \\
5 \cdot 5 \\
2 \cdot 1 \\
1 \cdot 4 \\
.7 \\
.7 \\
.7\end{array}$ \\
\hline
\end{tabular}

had committed at least one of the three most common "serious" offences (larceny, breaking and entering, and malicious damage).

It is difficult to find data on delinquency prevalence from other sources. This is because it is comparatively rare in delinquency studies to take a population of juveniles and ascertain which members of it have ever been found delinquent. The majority of delinquency studies have been carried out on juveniles brought before courts or even on those in reform institutions, and do not give an accurate estimate of the proportion of the general population that is delinquent.

A few studies, however, do yield results of this kind. Ferguson (1952), studying 1,349 Glasgow boys who left school at the minimum age (then 14) in 1947 , found that $5 \cdot 4$ per cent. had been convicted by the time they left school, and $12 \cdot 2$ per cent. by their 18th birthday. Ball, Ross, and Simpson (1964) gave a prevalence in 15 -year-old boys of $14 \cdot 14$ per cent. in a metropolitan area in the U.S.A., but this was arrived at by an indirect and possibly inaccurate method, since they did not attempt to obtain police records for the whole of a population at large, but inferred prevalence rates from the number of juveniles of various ages in the population and the annual incidence of first offences at the several ages. This article also gives an extensive bibliography of the American sources on delinquency prevalence, to which the reader is referred; the consensus of these sources indicates a prevalence of about 20 per cent. in boys by the age of 18 , though in one area of "high delinquency" a figure of 59 per cent. was recorded! The present writer is engaged on a study of boys in the area in which the school studied in this paper is situated; he has drawn a sample of 2,000 boys from this area and, by inspecting police records, has ascertained that about 15 per cent. were delinquent by the 15 th birthday and 29 per cent. by the 18 th birthday.

It must be emphasized that delinquency prevalence, like all other statistics of crime, is affected by a diversity of factors besides the actual amount of illegal activity in a community.

The more important of these contributory factors are:

(1) The mode of police activity; e.g. it is commonly held that, since the Children and Young Persons Act of 1933, the police have been less summary in their way of dealing with offending juveniles, that is, they have been more inclined to prosecute juveniles than to dismiss them with a warning, and that this accounts in part for the apparent increase in juvenile delinquency.

(2) The readiness of the public to report offences; perhaps for the same reason, the attitude of the public towards offending juveniles has undergone a similar change.

(3) The amount of police activity; it is likely that the more efficient the police, the greater the proportion of illegal acts detected. Of course, police efficiency will also reduce the amount of crime committed.

All these factors may vary with place as well as time and may account to an uncertain extent for the differences in delinquency prevalence reported in the various studies referred to above.

\section{RESULTS}

The analysis is set out in Tables II-IV (overleaf).

Table II presents the distribution of replies to the second question asked at the interview, that about last year's smoking habits. It will be seen that the boys who were caned for smoking were in general heavier smokers than those who were not; this difference reaches a very high level of significance. It is also true that delinquents smoke more than non-delinquents, but this tendency is considerably less marked. although it achieves statistical significance.

Table III gives the distribution of replies to the first question, about present smoking habits. The difference between caned and uncaned boys remains very highly significant, and that between delinquent and non-delinquent boys is, as before, comparatively weak although significant.

In Table IV, boys are grouped according to whether they had increased, decreased, or not changed their smoking habits between the two dates, according to their replies to the two questions. Changes within a scale category, e.g. from seven to twelve cigarettes per week, are ignored, and "same" includes those who claimed to be non-smokers at both dates. Taking all boys together, more decreased their cigarette consumption than increased; thus a general decline in smoking over the year is indicated 
TABLE II

1961 SMOKING HABITS (AS RECALLED IN 1962) BY CANING AND DELINQUENCY

\begin{tabular}{|c|c|c|c|c|c|c|c|c|c|c|c|}
\hline \multicolumn{5}{|c|}{ Boys } & \multicolumn{6}{|c|}{ Cigarettes per Week } & $x^{2}(2 \text { d.f. })^{*}$ \\
\hline \multirow[t]{2}{*}{ Caned } & \multicolumn{3}{|c|}{$\begin{array}{l}\text { Delinquent } \\
\text { Non-delinquent .. }\end{array}$} & $\begin{array}{l}\ldots \\
\therefore\end{array}$ & \multirow{2}{*}{$\begin{array}{c}\begin{array}{c}\text { Non- } \\
\text { smoker }\end{array} \\
1 \\
2 \\
3(13 \%)\end{array}$} & \multirow{2}{*}{$\begin{array}{c}<5 \\
\frac{1}{1} \\
2(9 \%)\end{array}$} & \multirow{2}{*}{$\frac{5-14}{4 \begin{array}{l}3 \\
7(30 \%)\end{array}}$} & \multirow{2}{*}{$\frac{15-24}{\frac{1}{5}}$} & \multirow{2}{*}{$\begin{array}{c}>24 \\
\begin{array}{c}2 \\
3\end{array} \\
5(22 \%)\end{array}$} & $\begin{array}{c}\text { Total } \\
9 \\
14\end{array}$ & \multirow{4}{*}{$\begin{array}{l}\text { All Caned } v \text {. } \\
\text { All Uncaned: } \\
48 \cdot 1(P<0 \cdot 001)\end{array}$} \\
\hline & Total & $\ldots$ & . & . & & & & & & $23(100 \%)$ & \\
\hline \multirow[t]{2}{*}{ Uncaned } & \multicolumn{3}{|c|}{$\begin{array}{l}\text { Delinquent } \\
\text { Non-delinquent ... }\end{array}$} & $\therefore$ & $\begin{array}{l}14 \\
70\end{array}$ & $\begin{array}{r}6 \\
14\end{array}$ & 8 & 1 & $\begin{array}{l}1 \\
2 \\
\end{array}$ & $\begin{array}{l}29 \\
94 \\
\end{array}$ & \\
\hline & Total & . & . & $\cdots$ & $84(68 \%)$ & $20(16 \%)$ & $15(12 \%)$ & $1(1 \%)$ & $3(2 \%)$ & $123(100 \%)$ & \\
\hline \multicolumn{2}{|c|}{$\begin{array}{l}\text { All Delinquent .. } \\
\text { All Non-delinquent }\end{array}$} & $\because$ & $\because$ & $\begin{array}{l}\cdots \\
\cdots \\
\end{array}$ & $15(39 \%)$ & $\begin{array}{r}7(18 \%) \\
15(14 \%) \\
\end{array}$ & $11(29 \%)$ & $\begin{array}{l}2(5 \%) \\
5(5 \%) \\
\end{array}$ & $\begin{array}{l}3(8 \%) \\
5(5 \%)\end{array}$ & $\begin{array}{l}38(100 \%) \\
108(100 \%)\end{array}$ & \multirow[t]{2}{*}{$\begin{array}{l}\text { All Delinquent } v \text {. } \\
\text { All Non-delinquent } \\
8.96(\mathrm{P}<0.02)\end{array}$} \\
\hline \multicolumn{2}{|c|}{ Grand Total .. } & $\ldots$ & .. & . & $87(60 \%)$ & $22(15 \%)$ & $22(15 \%)$ & $7(5 \%)$ & $8(5 \%)$ & $146(100 \%)$ & \\
\hline
\end{tabular}

Note: In all Tables, where percentages fail to add to exactly 100 per cent., the error is due to rounding to the nearest 1 per cent,

* Here and in Table III, Columns " $<5$ " and "5-14" have been grouped together in computing $\chi^{2}$, as have columns "15-24" and " $>24$ ". For this reason $\chi^{2}$ has 2 degrees of freedom in each case.

TABLE III

1962 SMOKING HABITS BY CANING AND DELINQUENCY

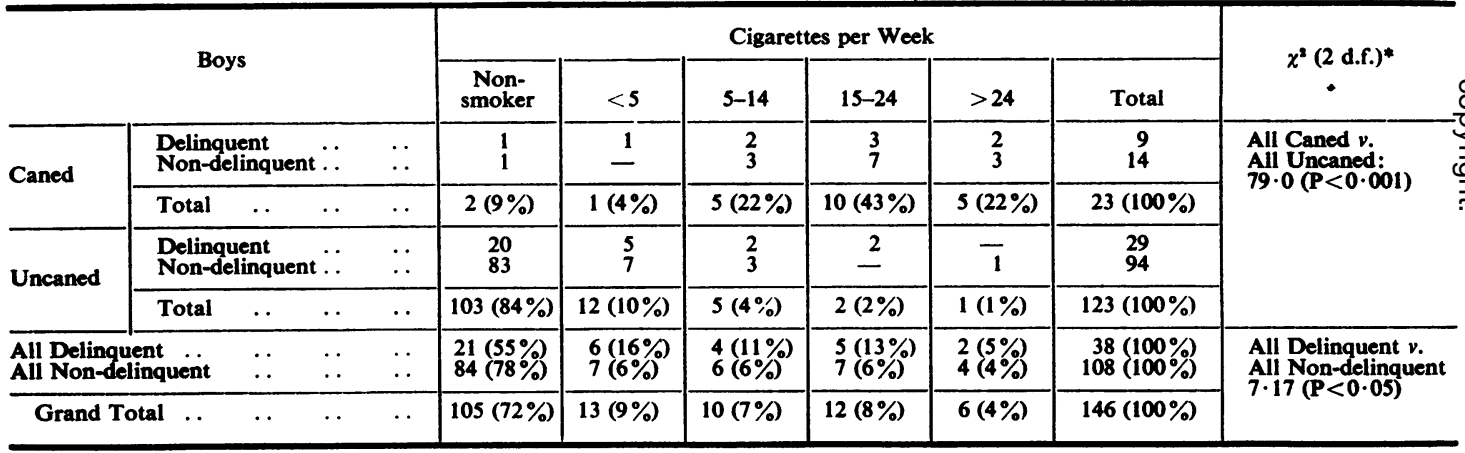

* See note to Table II.

TABLE IV

CHANGE IN SMOKING HABITS, 1961-62, BY CANING AND DELINQUENCY

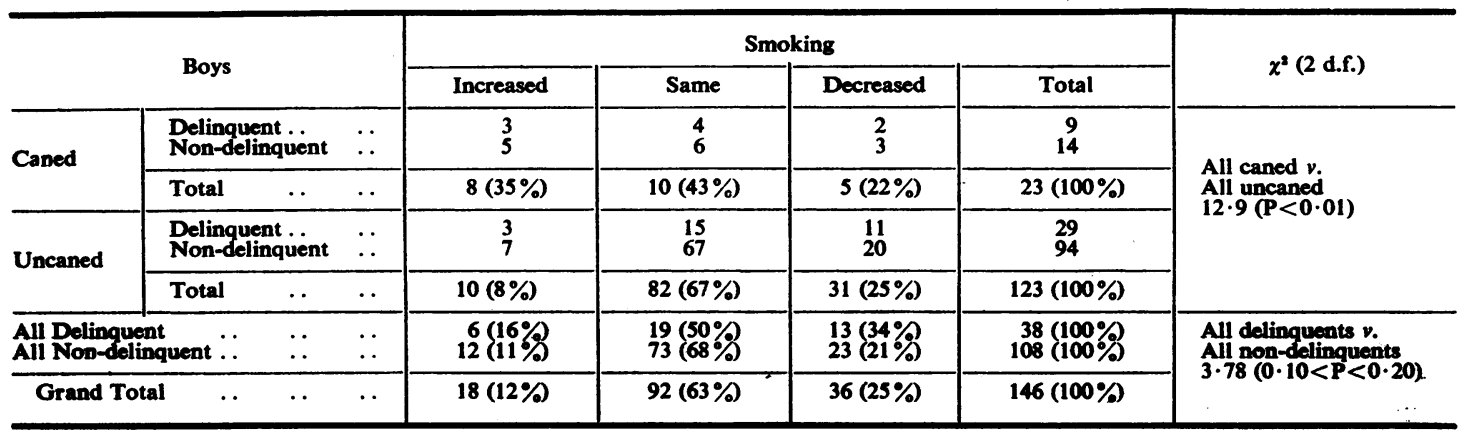


The statistical significance of this decline is best indicated by performing the $\chi^{2}$ test upon the grand totals of Tables II and III; when this is done a $\chi^{2}$ of $10 \cdot 10$ with four degrees of freedom is found, which has a probability of less than 0.05 .

It is clear from Table IV that the caned boys increased their smoking while the uncaned boys decreased. This difference is highly significant. No similar difference can be found between the delinquent and non-delinquent boys. In fact, when the caned and uncaned boys are considered separately, the pattern of change in smoking habits is similar for delinquents and non-delinquents. There would even appear to be a slightly greater general decrease in smoking in the delinquents ( 34 per cent.) than in the non-delinquents (21 per cent.), but this should be discounted in view of the fact that a greater proportion of non-delinquents than delinquents were non-smokers at the beginning of the year (see Table II) and thus were incapable of appearing as decreasers. Table $\mathrm{V}$ shows that there was no significant association between being caned for smoking and being a delinquent.

TABLE V

RELATIONSHIP BETWEEN BEING CANED FOR SMOKING AND DELINQUENCY

\begin{tabular}{|c|c|c|c|c|c|}
\hline Boys & & & Caned & Not Caned & Total \\
\hline Delinquent & . & .. & 9 & 29 & 38 \\
\hline Non-delinquent & . & .. & 14 & 94 & 108 \\
\hline Total & . & $\ldots$ & 23 & 123 & 146 \\
\hline
\end{tabular}

Table VI shows that the smoking habits found in the present study do not differ greatly from those reported in two other British studies. The Todd figures are taken from Todd (1962, p. 60), and relate to a national sample of boys, no distinction being made between those at different types of school. This source distinguishes between boys interviewed alone and boys interviewed with others present, and the former have been selected for this Table in order to achieve the maximum comparability with the present study. The London School of Hygiene figures are from Table IV in Public Health Department, London School of Hygiene (1959), and refer to boys in certain London secondary modern schools.

\section{Discussion}

\section{(1) Smoking and Delinquency}

Dimond (1964) has shown that approved school boys are very much heavier smokers than the general population of boys of comparable age. From the present data, it appears that a similar, but much weaker, difference exists between delinquents in the community and non-delinquent boys. Approved school boys are, of course, a highly selected sub-class of delinquents, so that it is not surprising that the difference reported by Dimond should be so much greater than that found here. These two studies taken together suggest that there is a direct relationship between smoking habits and the "seriousness" of delinquency.

\section{(2) General Trends in Smoking}

Caned boys were heavier smokers than uncaned boys, at both dates. This may be taken as indicating the general justice with which caning was administered. Apparently there was also a general decrease in smoking between the two dates, in spite of the fact that the boys had become one year older in this time and that smoking in boys has often been shown to increase with age (e.g. Public Health Department, London School of Hygiene, 1959; Nilsen, 1959).

TABLE VI

COMPARISON OF SMOKING HABITS RECORDED IN PRESENT STUDY WITH FIGURES FROM OTHER SOURCES (Percentages)

\begin{tabular}{|c|c|c|c|c|c|c|c|}
\hline \multirow{2}{*}{\multicolumn{2}{|c|}{ Source of Data }} & \multicolumn{6}{|c|}{ Cigarettes per Week } \\
\hline & & Non-smoker & $<5$ & $5-14$ & $15-24$ & $>24$ & $N(=100 \%)$ \\
\hline $\begin{array}{l}\text { Present Study } \\
1961 \text { (recalled) } \\
1962\end{array}$ & $\begin{array}{l}\text { All boys } \\
\text { All boys }\end{array}$ & $\begin{array}{l}60 \\
72\end{array}$ & $\begin{array}{r}15 \\
9\end{array}$ & $\begin{array}{r}15 \\
7\end{array}$ & $\begin{array}{l}5 \\
8\end{array}$ & $\begin{array}{l}5 \\
4\end{array}$ & $\begin{array}{l}147 \\
147\end{array}$ \\
\hline $\begin{array}{l}\text { Todd, } 1962 \\
1961 \text { National Survey, } \\
\text { boys interviewed alone }\end{array}$ & $\begin{array}{l}\text { Age 12 } \\
\text { Age 13 } \\
\text { Age 14 }\end{array}$ & $\begin{array}{l}86 \\
69 \\
66\end{array}$ & $\begin{array}{l}14 \\
25 \\
22\end{array}$ & $\begin{array}{l}\mathbf{2} \\
\mathbf{3} \\
\mathbf{8}\end{array}$ & \multicolumn{2}{|c|}{$\begin{array}{l}0^{*} \\
3 \\
5\end{array}$} & $\begin{array}{l}199 \\
238 \\
234\end{array}$ \\
\hline $\begin{array}{l}\text { London School of Hygiene, } 1959 \\
\text { Boys in secondary modern schools }\end{array}$ & $\begin{array}{l}\text { Age } 12 \\
\text { Age 13 } \\
\text { Age } 14\end{array}$ & \multicolumn{2}{|c|}{$\begin{array}{l}90 \\
79 \\
70\end{array}$} & \multicolumn{3}{|c|}{$\begin{array}{l}10 t \\
21 \\
30\end{array}$} & $\begin{array}{l}246 \\
277 \\
243\end{array}$ \\
\hline
\end{tabular}

Note: In constructing this Table, the one boy who had left the district in 1964 has been included; for this reason $N=147$, and the percentage distributions differ slightly from those given in Tables II and III.

- Fifteen or more cigarettes per week. 
Todd and Laws $(1958,1959)$ have cast considerable doubt on the validity of statements about past smoking habits. In view of their evidence the methods used in the present study require defence. Firstly Todd's and Laws's conclusions were based on a study mainly of men aged 35 and over, and it is likely that among schoolboys, who are necessarily new to the habit and conscious both of its novelty and of the status it gives them among their peers, details of past smoking habits can be recollected with greater accuracy. Secondly, the difference between uncaned boys and caned boys (that the latter have apparently increased their smoking while the former decreased) is difficult to explain except as a real difference.

It should be mentioned that a number of boys at their interviews referred, unprompted, to the risk of lung cancer associated with smoking; it appears therefore that this risk was well known to the boys in general, and so the apparent overall decline in smoking may perhaps be interpreted as showing that anti-smoking publicity has some effect on boys at an age when the smoking habit is frequently acquired.

\section{(3) Smoking and the Effect of Caning}

Had the caned boys reduced their smoking while the uncaned boys increased or maintained theirs, it would have been possible to claim that evidence had been found that caning had a reformative effect. The actual results indicate the contrary. A number of hypotheses may be put forward to account for these results.

First, we may suppose the reformative effect to be present; in this case we must explain why it is concealed. This leads to two distinct types of explanation, here called $(a)$ and $(b)$ :

(a) That the reformative effect is over-ridden by another, more powerful, effect in the opposite direction. Thus, the caned boys were of such a sort that they would have increased their smoking far more had they not been caned; caning only reduced the magnitude of the change. It may even be suggested that heavy smoking itself disposes one to increasing one's smoking still further, and that since the caned boys were heavy smokers, they would in any case have increased their smoking. The number of heavy smokers in the uncaned group, however, is too small for it to be possible to examine this suggestion on the present data.

(b) Alternatively, one may suppose that there is a reformative effect but that the data are subject to a systematic error which conceals it. A possibility of this sort is that caned boys, for temperamental or social reasons, were more inclined to boast about their smoking habits; but while this might account for their appearing to be generally heavier smokers, it does not so easily account for their increase in smoking.

Two further explanations are possible:

(c) We may accept the trends as real and suppose that, so far from being reformative, caning may actually aggravate the forbidden behaviour. This possibility is discussed by Clegg (1962), who reports an inquiry into caning and discipline in a sample of schools in the West Riding of Yorkshire. In his study, caning was found to be used more frequently in those schools where behaviour was rated poor. The assessment of behaviour was confirmed by the fact that schools with "poor" behaviour tended to have higher juvenile court appearance rates. Just as the present study shows that heavy smokers were caned more, so Clegg shows that ill-behaved children are caned more; and both studies suggest that it is possible that caning may have a deleterious effect. Although Clegg considers this view implausible, he quotes two cases of schools where a reduction of misbehaviour was associated with the discontinuance of caning; he prefers, however, to regard a high caning rate as a symptom and not as a cause of bad behaviour.

(d) The simplest hypothesis, which for the present seems to fit the facts, is that caning has no effect in either direction. The evidence is, of course, inconclusive. Conclusive evidence could only be obtained by a controlled trial; in this, some smokers, randomly selected, would be caned, and the others dealt with in some other way (e.g. reprimanded, or put in detention). After some lapse of time a comparison would be made between the smoking habits of those dealt with in different ways.

Controlled trials, though commonplace in medicine, are rare in penology, chiefly because of the difficulty of accommodating them within the legal system. The idea of randomizing sentences is often thought to be repugnant to justice. In the writer's opinion, this view is mistaken whenever the relative effectiveness of the different punishments among which the choice must be made is not known. Still, in view of the legal difficulties, it would seem to be easier to introduce randomization into the disciplinary systems of closed institutions, such as schools, than to fit it into the system of public justice. 


\section{SUMMARY}

In a secondary modern school in which caning was used as a punishment for smoking, no evidence has been found that the punishment had a reformative effect; it is suggested that a controlled trial would be necessary to find evidence for such an effect.

Caned boys were considerably heavier smokers than uncaned boys.

26 per cent. of the boys studied had been classified as delinquent in police records by a date at which their mean age was 15 years 4 months.

Delinquent boys were significantly heavier smokers than non-delinquents, but the difference was not as marked as that between caned and uncaned boys.

There was an apparent decline in smoking over a year. This may be due to errors of recall but is more likely to be real; if so it may be the effect of cancer propaganda.

There was no significant association between delinquency and being caned for smoking.
I wish to thank Prof. A. L. Cochrane for suggesting and encouraging this study, and the Chief Constable, the Local Education Authority, and the Headmaster and staff of the school for their kind co-operation and help.

\section{REFERENCES}

Ball, J. C., Ross, A., and Simpson, A. (1964). Amer. sociol. Rev., 29, 90.

Clegg, A. B. (1962). "Caning, Behaviour, and Delinquency in Secondary Schools". West Riding County Council Education Committee, Wakefield.

Dimond, S. J. (1964). Brit. J. prev. soc. Med., $18,52$.

Ferguson, T. (1952). "The Young Delinquent in his Social Setting", (Nuffield Foundation). Oxford University Press, London.

Nilsen, E. (1959). Brit. J. prev. soc. Med., 13, 5.

Public Health Department, London School of Hygiene and Tropical Medicine (1959). Ibid., 13, 1.

Todd, G. F., editor (1962). "Statistics of Smoking in the United Kingdom". Tobacco Manufacturers' Standing Committee Research Papers No. 1, 3rd ed. London. and Laws, J. T. (1958, 1959). "The Reliability of Statements about Smoking Habits". Tobacco Manufacturers' Standing Committee Research Papers No. 2, 1 st and 2nd ed. London. 